\title{
The Aicardi-Goutières syndrome (familial, early onset encephalopathy with calcifications of the basal ganglia and chronic cerebrospinal fluid lymphocytosis)
}

\author{
J L Tolmie, Paul Shillito, Rhiannon Hughes-Benzie, J B P Stephenson
}

\begin{abstract}
Aicardi-Goutières syndrome (Mendelian inheritance in man Catalog No *225750) is an autosomal recessive encephalopathy which causes developmental arrest, intracerebral calcification, and white matter disease in the presence of chronic cerebrospinal fluid lymphocytosis, and a raised level of cerebrospinal fluid interferon-alpha (IFN- $\alpha$ ). Diagnosis requires the presence of progressive encephalopathy with onset shortly after birth, and characteristic clinical neurological and neuroimaging signs together with chronic CSF lymphocytosis. The syndrome has superficial resemblance to the neurological sequelae of congenital infection, thus a rigorous search for microbiological and serological evidence of embryopathic infections should be carried out in each case.
\end{abstract}

(F Med Genet 1995;32:881-884)

Jean Aicardi and Françoise Goutières are eminent French paediatric neurologists who described the syndrome bearing their name in 1984. ${ }^{1}$ Their original report was a detailed account of eight children affected by a very severe, familial encephalopathy diagnosed shortly after birth which was fatal or caused persistent vegetative state from early childhood. The neurological phenotype comprised acquired microcephaly with intracerebral calcification and white matter disease, spasticity, dystonia, visual inattention, and abnormal eye movements. A most striking abnormality was chronic cerebrospinal fluid lymphocytosis in the absence of other evidence of infection by any known embryopathic pathogen.

Although Aicardi and Goutières identified cases with a similar clinical course and intracranial calcification in older neurological publications, ${ }^{2-5}$ their syndrome is uncommon. Since 1984 we have observed only two cases in our catchment population where there are 30000 births per year. The total number of published cases is also uncertain because of difficulties with case definition, for example, is cerebrospinal fluid lymphocytosis an absolute requirement for diagnosis? Nevertheless, allowing some latitude in the interpretation of pre-1984 publications and also other reports where cases have been investigated to a variable extent, there are nearly 30 reported cases..$^{1-11}$ Although Aicardi-Goutières syndrome is rare, its clinical genetic importance is exaggerated by the high chance that its symptoms and signs may be mistaken for the neurological sequelae of a non-genetic congenital infection.

\section{Clinical features and natural history}

Typically, the antenatal history is uneventful and birth weight at term is normal. The head circumference (OFC) at birth is usually normal

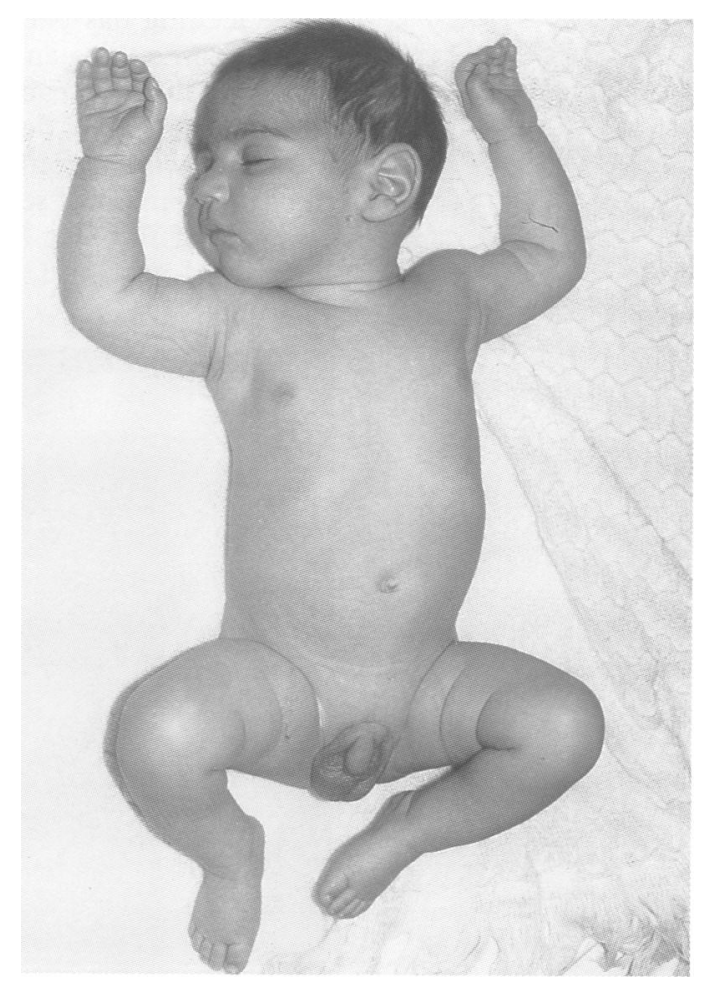

Figure 1 Non-dysmorphic, hypotonic infant with the encephalopathy of Aicardi-Goutières syndrome (see fig 3 for cranial $C T$ appearance). 


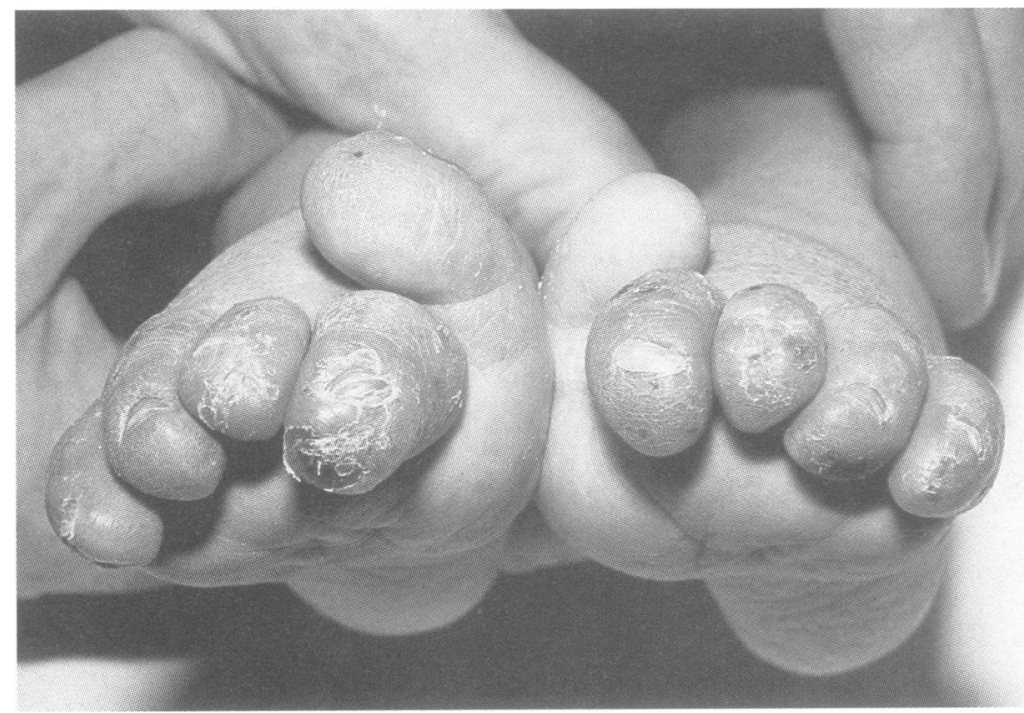

Figure 2 Severe, unexplained chilblains which developed after the second birthday of the infant depicted in fig 1. were not associated with any coolness of the extremities nor any detectable immunological abnormality. Furthermore, the lesions did not respond to vasodilator therapy.

\section{Neuroimaging investigations}

When the encephalopathy is first diagnosed, a skull $x$ ray may show numerous small areas of intracranial calcification while cranial ultrasound scan may confirm periventricular calcification with normal ventricles and little or no atrophy. Alternatively, calcification may be absent from these initial images. ${ }^{16}$ Progressive periventricular and basal ganglia calcification is the most constant finding but there may also be calcification in the cerebrum and cerebellum. However, the extent of intracerebral calcification does not correlate with the severity of the clinical picture. Serial cranial CT scans show progressive cerebral atrophy with loss of white matter (fig 3). Magnetic resonance studies have confirmed the white matter abnormalities with increased intensity of the T2 weighted signal. ${ }^{9}$

or slightly reduced in comparison with birth weight centile. Presenting symptoms and neurological signs of encephalopathy are noted in the first days or weeks of life with poor feeding, irritability, and truncal hypotonia coinciding with the onset of poor head growth (fig 1). Limb spasticity and intermittent dystonic posturing are usual but seizures are not prominent and the electroencephalographic record is frequently unremarkable apart from some diffuse slow wave activity. Abnormal eye movements with visual inattention are typically present by the age of 3 months but ophthalmological examination and visual evoked potentials are normal. Rapid progression to a persistent vegetative state is usual. Death occurs in the first year in about $25 \%$ of cases. Tube feeding has been used to overcome oral feeding difficulties and an affected infant may thrive, although head growth virtually ceases and the OFC may decline to $7 \mathrm{SD}$ below the mean. In two older affected children, we noted the development of severe chilblains and acrocyanosis of the feet (fig 2). This occurred in their third year and, curiously, the chilblains

\section{Investigations}

To clinch the diagnosis of Aicardi-Goutières syndrome, serial lumbar punctures are required to establish that sterile, chronic cerebrospinal fluid lymphocytosis is present. The cell count varies from 20 to 80 per cubic mm, lymphocytes make up $80 \%$ or more of the total, and, in one case, there were decreased subpopulations of activated and avid $T$ cells and a predominance of non-T, non-B, and null lymphocytes. ${ }^{8}$ Assay of cerebrospinal fluid IFN- $\alpha$ provides useful additional evidence if the level is significantly above the normal value of less than 2 IU. Overall, these results are compatible with a localised inflammatory process, yet protein and glucose levels are normal in most cases and no infectious agent has ever been identified. Nevertheless, important additional investigalogical tests for prenatal infection with toxoplasma, rubella, cytomegalovirus, and herpes tions to undertake are microbiological and sero-
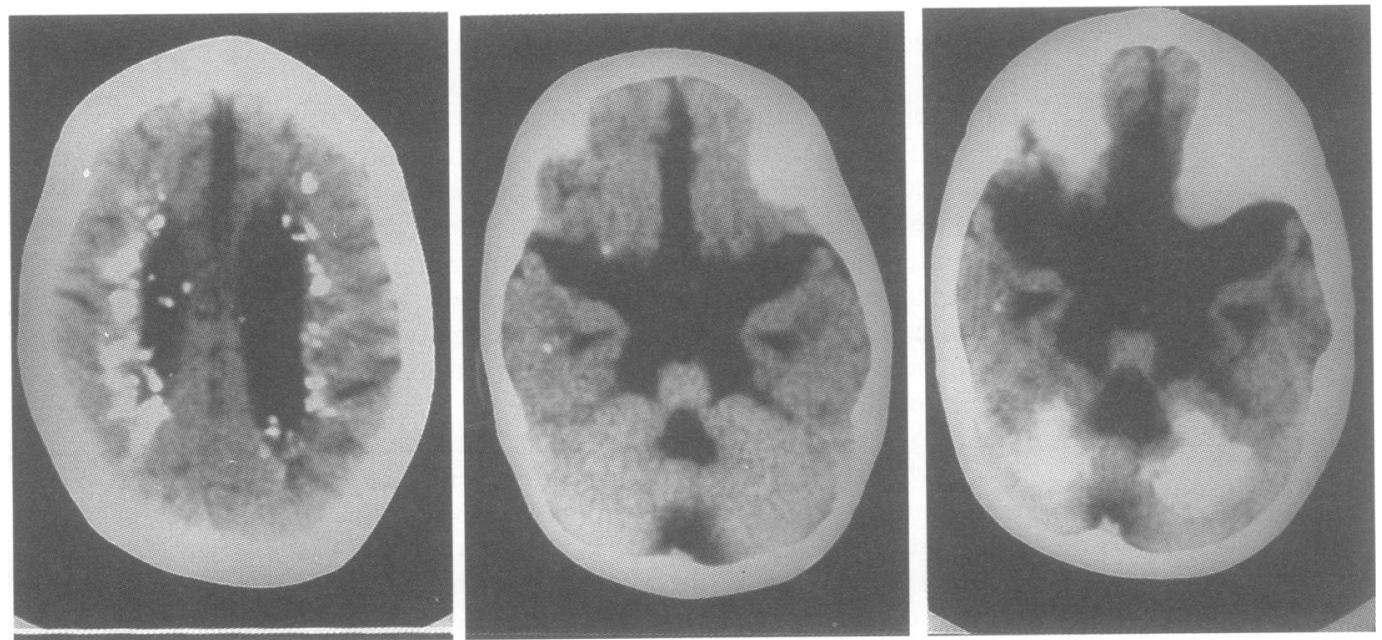

Figure 3 Serial cranial CT scans showing periventricular calcification (left), progressive loss of central white matter (centre and right), and progressive calcification in the dentate nuclei (centre and right). Scans were performed on the patient depicted in fig 1. 
Differential diagnoses of Aicardi-Goutières syndrome (categories 1-3 were derived from Billard et al ${ }^{13}$ ).

\begin{tabular}{|c|c|c|}
\hline \multicolumn{2}{|c|}{ Clinical syndrome } & \multirow{2}{*}{$\begin{array}{l}\text { Comment } \\
\text { Different autosomal recessive varieties, for example, early onset } \\
\text { Cockayne syndrom }{ }^{16} \text { or encephalopathy with growth hormone } \\
\text { deficiency. }{ }^{17} \text { Necropsy important to identify autosomal recessive } \\
\text { sudanophilic leucodystrophies (MIM 260600) }\end{array}$} \\
\hline (1) & $\begin{array}{l}\text { Cerebral calcification, demyelination, and } \\
\text { prominent additional features such as retinal } \\
\text { dystrophy }\end{array}$ & \\
\hline (2) & $\begin{array}{l}\text { Cerebral calcification with CT or MRI } \\
\text { evidence of prenatal anoxic-ischaemic lesions }\end{array}$ & $\begin{array}{l}\text { Sporadic disorders, }{ }^{13} \text { antenatal and perinatal history frequently } \\
\text { uninformative but non-progressive neurological signs and absence of } \\
\text { progressive brain atrophy on neuroimaging are highly suggestive }\end{array}$ \\
\hline (3) & $\begin{array}{l}\text { Cerebral calcification, acquired microcephaly, } \\
\text { encephalopathy, and CSF lymphocytosis }\end{array}$ & $\begin{array}{l}\text { Autosomal recessive Aicardi-Goutières syndrome: encephalopathy with } \\
\text { white matter disease and progressive brain atrophy }\end{array}$ \\
\hline (4) & $\begin{array}{l}\text { Cerebral calcification and leucodystrophy with } \\
\text { or without a high CSF protein level, but } \\
\text { normal CSF cell count }\end{array}$ & $\begin{array}{l}\text { Autosomal recessive inheritance: note similarity of cases }{ }^{12-14} \text { to Aicardi- } \\
\text { Goutières. Also, note reports of cerebral calcifications with cerebellar } \\
\text { hypoplasia }{ }^{18} \text { and autosomal recessive leucoencephalopathy affecting } \\
\text { North American Indians. }{ }^{190} \text { Measurement of fluid IFN- } \alpha \text { should be } \\
\text { considered (P Lebon, personal communication) }\end{array}$ \\
\hline (5) & $\begin{array}{l}\text { Other cerebral calcification syndromes closely } \\
\text { mimicking sequelae of intrauterine infection }\end{array}$ & $\begin{array}{l}\text { Autosomal recessive, with prominent hepatosplenomegaly and } \\
\text { haematological abnormalities, }{ }^{2122} \text { but reports of affected brothers with } \\
\text { seizures and no haematological abnormalities may suggest an X linked } \\
\text { variety }{ }^{2324}\end{array}$ \\
\hline (6) & $\begin{array}{l}\text { Miscellaneous syndromes causing } \\
\text { encephalopathy in infancy or intracranial } \\
\text { calcification or both }\end{array}$ & $\begin{array}{l}\text { Many metabolic, neuroectodermal, and dysmorphic syndromes diagnosed } \\
\text { by history, clinical and biochemical findings. }{ }^{25} \text { Fumarase deficiency } \\
\text { (MIM 136850), multiple carboxylase deficiency (MIM } 253260 \& \\
253270 \text { ), molybdenum cofactor deficiency (MIM } 252150 \text { ), pyruvate } \\
\text { dehydrogenase deficiency (MIM } 312170 \text { ), and mitochondrial cytopathy } \\
\text { (MIM } 516060 \text { ) are notable causes of early onset encephalopathy while } \\
\text { carbonic anhydrase II deficiency (MIM } 259730 \text { ) and dysosteosclerosis }{ }^{15} \\
\text { present later with prominent cerebral calcifications. }\end{array}$ \\
\hline
\end{tabular}

simplex virus which should be negative in blood, urine, and other body secretions. Further serological tests for human immunodeficiency virus should also be demonstrably normal. To date, no chromosomal abnormality has been found.

Neuropathological findings have not been presented in recently described cases of Aicardi-Goutières syndrome. However, among reports of infants with similar findings ${ }^{2-412-14}$ (comprising leucoencephalopathy and cerebral calcifications with or without raised CSF protein levels but no mention of CSF leucocytosis), documented brain histological abnormalities include calcifications of the basal ganglia, cerebral and cerebellar hemispheres, reduced white matter with poorly staining myelin and gliosis, and an inflammatory type meningeal reaction.

\section{Differential diagnosis}

Patients with neurodegeneration and cerebral calcifications have presented long standing nosological problems and an informative review was written 35 years ago by Melchior et al. ${ }^{4}$ These authors noted that Fahr's disease was the eponym given to cases with the predominant finding of "idiopathic nonarteriosclerotic calcifications of the brain", following Fahr's description of a 55 year old man with symmetrical calcification of the basal ganglia and rapidly progressive neurological disease. Melchior et $a l^{4}$ also distinguished from Fahr's disease a familial genetic encephalopathy of infancy, akin to Aicardi-Goutières syndrome, with demyelination and cerebral calcification. On its own, intracerebral calcification is not a particularly good diagnostic handle and an extensive list of nearly 100 causes was supplied in a case report of a child with dysosteosclerosis. ${ }^{15}$ Fortunately, though, the vast majority of these listed syndromes are easily distinguished if the Aicardi-Goutières syndrome is defined as a severe, progressive encephalopathy diagnosed shortly after birth with calcification in the basal nuclei and chronic excess of white cells in cerebrospinal fluid. The table provides a shorter list of references to groups of disorders which need to be considered in the differential diagnosis of Aicardi-Goutières syndrome.

\section{Aetiology and genetics}

Case reports have documented parental consanguinity and the recurrence of the syndrome in sibs of diverse ethnic origins. ${ }^{1711}$ Thus, there is general agreement that an autosomal recessive gene causes this condition. Nevertheless, the syndrome's resemblance to neurodegeneration caused by embryopathic infection is long appreciated. ${ }^{1}$ Moreover, there is a puzzling rise of cerebrospinal fluid IFN- $\alpha,{ }^{11}$ a cytokine which has the ability to protect cells against a wide range of DNA and RNA viruses as well as having antitumour and immunomodulatory effects through binding specific receptors on target cells and altering gene expression and post-transcriptional protein expression. ${ }^{26}$ Raised levels of IFN- $\alpha$, but not IFN- $\gamma$, were found in cerebrospinal fluid or sera or both in seven out of eight patients with Aicardi-Goutières syndrome with negative serology tests. ${ }^{11}$ The IFN- $\alpha$ levels in cerebrospinal fluid were high at birth and then slowly declined but were still present in two out of three patients tested at the age of 5 years. The reason for persistent production of IFN$\alpha$ in patients with familial encephalopathy is unknown but it is speculated that there may be an underlying pleiotropic inherited defect which causes leucodystrophy and defective regulation of IFN- $\alpha$ synthesis, or an unknown viral infection associated with an autosomal recessive abnormality of host response. ${ }^{11}$

Prenatal diagnosis of Aicardi-Goutières syndrome has not been accomplished although consideration may be given to measuring IFN$\alpha$ in a sample of fetal blood or cerebrospinal fluid. This procedure would be risky and speculative, so it is gratifying to record that Professor Lebon has started collection of DNA samples from suitable families for the purpose of molecular genetic studies. 
We thank Professors Aicardi, Goutières, and Lebon and $\mathrm{Dr}$ Bryony Fredericks for commenting on clinical and radiological features of our cases and also for assaying IFN- $\alpha$ levels in blood and CSF.

1 Aicardi J, Goutières F. A progressive familial encephalopathy in infancy with calcifications of the basal ganglia and chronic cerebrospinal fluid lymphocytosis. Ann Neurol 1984;15:49-54.

2 Hallervorden I. Über diffuse symmetrische kalkablagerungen bei einem krankheitsbild mit mikrocephalieund meningoencephalitis. Arch Psychiatr Zeitschr Neurl 1950;

184:579-600.
3 Jervis GA. Microcephaly with extensive calcium deposits and demyelination. F Neuropathol Exp Neurol 1954;13: 318-29.

4 Melchior JC, Benda CE, Yakovlev PI. Familial idiopathic calcifications in childhood. Am $\mathcal{F}$ Dis Child 1960;99:10117.

5 Lyon G, Robain O, Phillipart M, Sarlieve L. Leukodystrophie avec calcifications strio-cérébelleuses, microcéphalie et nanism. Rev Neurol (Paris) 1968;119:197-210.

6 Giroud M, Gouyon JB, Chaumet F, et al. A case of familial encephalopathy in infancy with calcification of the basal
ganglia and chronic cerebrospinal fluid lymphocytosis. Child's Nerv Syst 1986;2:47-8.

7 Mehta L, Trounce JQ, Moore JR, Young ID. Familial calcification of the basal ganglia with cerebrospinal fluid pleocytosis. $\mathcal{F}$ Med Genet 1986;23:157-60.

8 Diament AJ, Machado LR, Cypel S, Ramos JLA. Síndrome de calcificações dos gânglios da base, leucodistrofia e de calcificações dos gânglios da base, leucodistrofia e pleocitose linfomonocitária crônicqa do líquido

9 Bönnemann CG, Meinecke P. Encephalopathy of infancy with intracerebral calcification and chronic spinal fluid lymphocytosis - another case of the Aicardi-Goutières syndrome. Neuropediatrics 1992;23:157-61.

10 Babbit DP, Tang T, Dobbs J, Berk R. Idiopathic familial cerebrovascular ferrocalcinosis (Fahr's disease) and review of differential diagnosis of intracranial calcification in children. Am $\mathcal{F}$ Radiol 1969;105:352-8.

11 Lebon P, Badoual J, Ponsot G, Goutières F, HèmeuryCukier F, Aicardi J. Intrathecal synthesis of interferonalpha in infants with progressive familial encephalopathy. f Neurol Sci 1988;84:201-8.

12 Razavi-Encha F, Larroche JC, Gaillard D. Infantile familial encephalopathy with cerebral calcifications and leukodystrophy. Neuropediatrics 1988;19:72-9.
13 Billard C, Dulac O, Bouloche J, et al. Encephalopathy with calcifications of the basal ganglia in children. A reappraisal of Fahr's syndrome with respect to 14 new cases. Neuropediatrics 1989;20:12-19.

14 Bolthauser E, Steinlin M, Boesch C, Martin E, Schubiger G. Magnetic resonance imaging in infantile encephalopathy with cerebral calcification and leukodystrophy. Neurowediatrics 1991;22:33-5.

15 Chitayat D, Silver K, Azouz EM. Skeletal dysplasia, intracerebral calcifications, optic atrophy, hearing impairment and mental retardation: nosology of dysosteosclerosis. Am f Med Genet 1992;43:517-23.

16 Patton MA, Gianelli F, Francis AJ, et al. Early onset Cockayne syndrome: case reports with neuropathological and fibroblast studies. F Med Genet 1989;26:154-9.

17 Bönnemann CG, Meinecke P. Reich H. Encephalopathy with intracerebral calcification, white matter lesions, growth hormone deficiency, microcephaly and retinal degeneration. Two siblings confirming a probably distinct entity. $\mathcal{F}$ Med Genet 1991;28:708-11.

18 Troost D, van Rossum A, Veiga Pires J, Willemse J. Cerebral calcifications and cerebellar calcification in two children: clinical radiologic and neuropathological studies: a separate neurodevelopmental entity. Neuropediatrics 1984;15: 102-9.

19 Black DN, Booth F, Watters GV, et al. Leucoencephalopathy among native Indian infants in northern Quebec and

20 Black DN, Watters GV, Andermann E, et al. Encephalitis among Cree children in Northern Quebec. Ann Neurol among Cree child

21 Burn J, Wickramasinghe HT, Harding B, Baraitser M. A syndrome with intracranial calcification and microcephaly in two sibs, resembling intrauterine infection. Clin Genet 1986;30:112-16.

22 Reardon W, Hockey A, Silbertstein P, et al. Autosomal recessive congenital intrauterine infection-like syndrome of microcephaly, intracranial calcification and CNS disease. Am $\mathcal{F}$ Med Genet 1994;52:58-65.

23 Baraitser M, Brett EM, Piesowicz AT. Microcephaly and intracranial calcification in two brothers. $f$ Med Genet 1983;20:210-12.

24 Ishitsu TS, Chikazawa I, Matsuda I. Two siblings with microcephaly associated with calcification of the cerebral white matter. Ipn f Hum Genet 1985;30:213-17.

25 Stephenson JBP, King MD. Handbook of neurological investigations. Revised edition London: Butterworth-Heivestigations. Revise.

26 Pfeffer LM, Constantinescu SN, Wang C. Transmembrane signalling by IFN- $\alpha$. Prog Mol Subcell Biol 1994;14:242-59. 